\title{
THE IMPACT OF THE TRIPLE HELIX MODEL ON THE LOCAL DEVELOPMENT OF WESTERN POLAND
}

\author{
Robert ROMANOWSKI \\ Poznan University of Economics, Department of Commerce and Marketing, Poznan; \\ robert.romanowski@ue.poznan.pl, ORCID: 0000-0002-8585-6806
}

\begin{abstract}
Purpose: The aim of this paper is to show the positive impact of public support for the relationships within the triple helix model on the local development of Western Poland (WP). Design/methodology/approach: The paper presents the econometric model based on backward stepwise multiple regression in which the explanatory variables were expenses aggregated into 44 categories dedicated to triple helix model. The model defines a theoretical framework for local innovation systems in 111 counties of WP (5 western voivodeships). An economic aggregate based on average salaries was chosen as a dependent variable, treated
\end{abstract} as a measure of local development.

Findings: Relationships diagnosed within triple helix model were supported by public expenditures from the European Union cohesion policy in 2007-2013. Two hypotheses were proposed in the paper. In the first one, a presumption was expressed for the positive impact of statistically significant expenditures on innovative activity, and technical and knowledge infrastructure for the local development of WP. The hypothesis was tested in basic and extended variants. In the second one, a presumption was expressed in which public expenditures on technical infrastructure were more influential for the local development of WP than expenditures on knowledge infrastructure. The first hypothesis was confirmed in both basic and extended variants. The second hypothesis could not be confirmed as a result of the research procedure. Importantly, bi-lateral synergy effects in the triple helix model within the researched counties of WP, positively influencing local development, are evident.

Research limitations/implications: The Triple helix model, treated as a template for creating local innovation systems, could be extended into quadruple helix model. Future research may include variables related to "society" as forth side supporting innovative processes in local economy.

Practical implications: The results of the regression model confirm the positive impact of expenses related to the broadly understood innovation activities on local development. In contrast, expenditure on technical infrastructure, representing the administration-business relationship, demonstrates a negative impact on the adopted local development measures.

Originality/value: the paper presents the methodology, that could be used in diagnosing trilateral relationships occurring at the interface of science-business-administration. In the research, only bilateral relations have been diagnosed at the interface of science-business and administration-science.

Keywords: Triple Helix Model, local innovation systems, counties of Western Poland. 


\section{Introduction}

Improving innovativeness of local government units, understood as improving the ability to innovate in an area, is one of the main priorities and objectives in the most important strategic documents of the European Union. i.e. the Lisbon Strategy (Office of the Committee for European Integration (UKIE, 2002, p. 4) and the Europe 2020 strategy (EC, 2010, p. 5). In view of the high risk of innovation for small and medium-sized enterprises, according to the first and second Schumpeterian hypothesis ${ }^{1}$, calls are being made for the creation of economic environments, usually in the form of regional and local innovation systems, whose task is to support innovation in enterprises and the simultaneous reduction of the mentioned risk for SMEs. It is assumed in fact that big companies can innovate without state protection. One of the concepts that are supposed to help in the formulation and implementation of measures to improve innovation is the creation and development of local innovation systems on the basis of the triple helix model (Etzkowitz, and Leydesdorff, 1995, p. 14-19). The aim of this paper is to demonstrate the positive impact of public support on the relationships formed within the triple helix model for the development of local counties in Western Poland. It was assumed that the counties of Western Poland form part of two Polish regions (NTS1) ${ }^{2}$ : i.e. the northwestern region, grouping West Pomeranian, Lubusz and Greater Poland voivodeships; and the southwestern region, which includes Lower Silesia and the Opole voivodeships. In total, the study included 111 counties of Western Poland.

\section{Public spending under the cohesion policy in Western Poland in 2007-2013}

The main assumptions of the cohesion policy in 2007-2013 were based on creating the conditions for increasing the competitiveness of the Polish economy based on knowledge and entrepreneurship, ensuring employment growth, as well as increasing the level of social, economic and spatial cohesion (NSRF, 2007, p. 40). A special role in cohesion policy is attributed to fostering innovation and stimulating innovative activity, which is the basis of the knowledge economy, in line with the Lisbon strategy (LS, 2000) and the Community Lisbon

\footnotetext{
1 The first Schumpeterian mark, formulated in 1912, points to small, mostly family businesses, run by "entrepreneurial in spirit" owners, as pioneers of innovation, because due to their flexibility they are able to grow faster than bureaucratic large companies. On the other hand, the second Schumpeterian hypothesis, formulated after World War II, points to large companies, especially operating under monopoly conditions, as major players in the innovation environment, as they are able to win large government contracts, usually military, which increase the level of innovation across the economy.

${ }^{2}$ Poland was divided into six groups of voivodeships, commonly referred to as macro-regions (Central Statistical Office, 2016), and the voivodeships are referred to as regions.
} 
Programme (CEC, 2005). In line with the Lisbon strategy, innovation, competitiveness, and entrepreneurship create a set of factors favouring economic and social development that determines the economic growth of countries. The most important document determining the basic objectives of cohesion policy and specifying the main directions of support for its instruments (which include the European Regional Development Fund, the European Social Fund and the Cohesion Fund) in the first, for Poland, full, seven-year programming perspective were the National Strategic Reference Framework 2007-2013 (NSRF, 2007), adopted by the Council of Ministers on 29 November 2006 (see Kokocińska, 2009). Implementation of the NSRF assumptions was done through the implementation of operational programmes, or executive documents in relation to the NSRF. A new development from the perspective of 2007-2013 was the partial decentralization of the management of the cohesion policy instrument funds, consisting in the creation of 16 Regional Operational Programmes, a separate one for each voivodeship. In addition to the regional programmes, since the beginning of 2007, several operational programmes for "Convergence" began operation, i.e. OP Innovative Economy, OP Human Capital, OP Infrastructure and Environment, OP Eastern Poland, and OP Technical Assistance. The data used in this paper come from projects implemented in all the operational programmes.

This paper assumes that the analysis of the impact of cohesion policy on local development would be carried out on the basis of econometric modelling using multiple regression equations. The modelling covered the main relationship, i.e. the impact of all the expenditure of the Cohesion Policy in 2007-2013 in Western Poland on local development divided into 111 counties (Table 1 ).

Table 1.

Expenditure on cohesion policy in the counties of Western Poland 2007-2013

\begin{tabular}{|c|l|c|c|c|}
\hline $\begin{array}{c}\text { Voivodeship } \\
\text { NTS 2 } \\
\text { (number of } \\
\text { counties) }\end{array}$ & \multicolumn{1}{|c|}{ Counties (NTS4) } & $\begin{array}{c}\text { Amount of } \\
\text { support under } \\
\text { the cohesion } \\
\text { policy (2007- } \\
\text { 2013) million } \\
\text { PLN * }\end{array}$ & $\begin{array}{c}\text { Value of funds } \\
\text { under the } \\
\text { cohesion policy } \\
\text { per capita in } \\
\text { PLN ** }\end{array}$ \\
\hline Lubusz (14) & $\begin{array}{l}\text { Go13 } \\
\text { Strzelecko-Drezdenecki, Sulęciński, } \\
\text { City of Gorzów Wielkopolski, } \\
\text { Krośnieński, Nowosolski, } \\
\text { Świebodziński, Zielonogórski, } \\
\text { Żagański, Żarski, Wschowski, City of } \\
\text { Zielona Góra }\end{array}$ & $1,021,470$ & $11,777.55$ & $11,530.00$ \\
\hline
\end{tabular}


Cont. table 1.

\begin{tabular}{|c|c|c|c|c|}
\hline $\begin{array}{c}\text { Greater } \\
\text { Poland (35) }\end{array}$ & $\begin{array}{l}\text { Jarociński, Kaliski, Kępiński, } \\
\text { Krotoszyński, Ostrowski, } \\
\text { Ostrzeszowski, Pleszewski, City of } \\
\text { Kalisz, Gnieźnieński, Kolski, Koniński, } \\
\text { Słupecki, Turecki, Wrzesiński, City of } \\
\text { Konin, Gostyński, Grodziski, } \\
\text { Kościański, Leszczyński, } \\
\text { Międzychodzki, Nowotomyski, } \\
\text { Rawicki, Wolsztyński, City of Leszno, } \\
\text { Chodzieski, Czarnkowsko-Trzcianecki, } \\
\text { Pilski, Wągrowiecki, Złotowski, } \\
\text { Obornicki, Poznański, Szamotulski, } \\
\text { Sredzki, Śremski, City of Poznań }\end{array}$ & $3,467,016$ & $33,287.29$ & $9,601.13$ \\
\hline $\begin{array}{c}\text { West } \\
\text { Pomeranian } \\
(21)\end{array}$ & $\begin{array}{l}\text { Białogardzki, Drawski, Kołobrzeski, } \\
\text { Koszaliński, Sławieński, Szczecinecki, } \\
\text { Świdwiński, Wałecki, City of Koszalin, } \\
\text { Choszczeński, Gryficki, Myśliborski, } \\
\text { Pyrzycki, Stargardzki, Łobeski, City of } \\
\text { Szczecin, Goleniowski, Gryfiński, } \\
\text { Kamieński, Policki, City of Świnoujście }\end{array}$ & $1,718,861$ & $23,972.89$ & $13,946.96$ \\
\hline $\begin{array}{c}\text { Lower } \\
\text { Silesia (29) }\end{array}$ & $\begin{array}{l}\text { Bolesławiecki, Jaworski, Jeleniogórski, } \\
\text { Kamiennogórski, Lubański, Lwówecki, } \\
\text { Zgorzelecki, Złotoryjski, City of Jelenia } \\
\text { Góra, Głogowski, Górowski, Legnicki, } \\
\text { Lubiński, Polkowicki, City of Legnica, } \\
\text { Dzierżoniowski, Kłodzki, Swidnicki, } \\
\text { Wałbrzyski***, Ząbkowicki, Milicki, } \\
\text { Oleśnicki, Oławski, Strzeliński, } \\
\text { Średzki, Trzebnicki, Wołowski, } \\
\text { Wrocławski, City of Wrocław } \\
\end{array}$ & $2,909,997$ & $37,163.32$ & $12,770.92$ \\
\hline Opole (12) & $\begin{array}{l}\text { Brzeski, Kluczborski, Namysłowski, } \\
\text { Nyski, Prudnicki, Głubczycki, } \\
\text { Kędzierzyńsko-Kozielski, } \\
\text { Krapkowicki, Oleski, Opolski, } \\
\text { Strzelecki, City of Opole }\end{array}$ & $1,004,416$ & $10,101.22$ & $10,056.81$ \\
\hline $\begin{array}{c}5 \text { out of } 16 \\
\text { voivodeships } \\
18 \text { out of } 66 \\
\text { sub-regions }\end{array}$ & 111 of $379 * * *$ counties & $\begin{array}{c}10.121 \text { out } \\
\text { of } 38.321 \\
\text { million }\end{array}$ & $\begin{array}{c}116,302.27 \\
\text { million out of } \\
473,771.78 \\
\text { million }\end{array}$ & $\begin{array}{c}11,490.32 \\
\text { (Poland } \\
12,363.24)\end{array}$ \\
\hline
\end{tabular}

Note:

* Projects which included the entire country without specifying regions have been omitted.

$* *$ values as of 30.09.2014.

*** The number of districts was reduced from 380 to 379 , since the calculations were performed for Wałbrzyski county and Wałbrzych according to the administrative state in the years 2007-2012.This change was dictated by the difficulty in analysing the changes during 2007-2013 in units that reflected their changing administrative and economic character. It was assumed that the separation of Walbrzych as a city with county rights from January 1 , 2013 did not result in serious changes in the size of the stream of public expenditure directed to this area in the seven-year period from 2007 onwards. Wałbrzyski county was included among the rural counties as of 2012.

Source: own elaboration. 
All contracts implemented throughout the country ${ }^{3}$ have been removed from the comparison due to the lack of opportunities for the analysis of any volatility at the level of regions and districts. Additionally, those contracts have been removed where the implementation had not been determined territorially.

The analysis included contracts that have been implemented in the voivodeship, because the amounts spent on the project were divided evenly over all the counties of the voivodeship. Each table (2-7) provides basic descriptive statistics for each category of intervention, i.e. the arithmetic mean, standard deviation, coefficient of variation, median, as well as minimum and maximum values. From the viewpoint of further analyses the most important statistic includes the coefficient of variation, whose range was between $43 \%$ and $973 \%$. This proves that the variables are intrinsically diverse (the coefficients for each category of intervention exceed $10 \%$ ).

The coefficient of variation generally assumes values in the range $0-100 \%$, which is a typical characteristic of variables characterized by a normal distribution or approaching a normal distribution. However, there are cases in which the standard deviation exceeds the value of the arithmetic mean, particularly when the distribution of a variable is far from normal. Variables describing the expenditure implemented as part of the cohesion policy by definition are asymmetrical, and therefore the value of the coefficient of variation can exceed $100 \%$. Principles of selection for econometric analysis with respect to the coefficient of variation tend to refer to the minimum value, which should not be less than $10 \%$. As stated by Parysek and Wojtasiewicz (1979, p. 14) features of a variable should be internally differentiated in the crosssection of the included research units.

The high coefficient of variation allows the adoption of all the variables corresponding to the expenditure to be carried out in the framework of priorities presented to the procedure of econometric study. With so many variables it is desirable to eliminate those that are either highly correlated, or are not statistically significant.

\footnotetext{
${ }^{3}$ In the adopted methodology of aggregating data by the creators of KSI SIMIK [PFE 2014] arithmetic apportioning of the amounts realized in the framework of such projects was adopted, i.e. the value of such projects was divided evenly into 16 voivodeships. This way of presenting the data means a lack of capacity to analyze the variation between counties.
} 
Table 2.

Key variable statistics representing independent variables in the counties $(N=111)$ for the dependent variable and for expenditure under the priority topic RESEARCH AND TECHNOLOGICAL DEVELOPMENT, INNOVATION AND ENTREPRENEURSHIP (variable RTD) $2007-2013$

\begin{tabular}{|c|c|c|c|c|c|c|c|c|}
\hline $\begin{array}{l}\text { Intervention } \\
\text { code }\end{array}$ & Variable & Priority & $\begin{array}{c}\text { Mean } \\
\text { (PLN per } \\
\text { capita) }\end{array}$ & $\begin{array}{c}\text { Standard } \\
\text { deviation } \\
\text { (PLN per capita) }\end{array}$ & $\begin{array}{c}\text { Volatility } \\
\text { (\%) }\end{array}$ & $\begin{array}{l}\text { Median } \\
\text { (PLN per } \\
\text { capita) }\end{array}$ & $\begin{array}{l}\text { Minimum } \\
\text { (PLN per } \\
\text { capita) }\end{array}$ & $\begin{array}{c}\text { Maximum } \\
\text { (PLN per } \\
\text { capita) }\end{array}$ \\
\hline 01 & $x_{1}$ & R\& TD activities in research centres & 9.47 & 65.01 & 686.26 & 0.00 & 0.00 & 659.00 \\
\hline 02 & $x_{2}$ & $\begin{array}{l}\text { R \& TD infrastructure (including physical plant, } \\
\text { instrumentation and high-speed networks linking } \\
\text { research centres) and specialized centres of } \\
\text { technological competence }\end{array}$ & 151.61 & 197.14 & 130.03 & 121.56 & 0.00 & $1,452.72$ \\
\hline 03 & $x_{3}$ & $\begin{array}{l}\text { Technology transfer and the improvement of } \\
\text { cooperative networks between SMEs, as well as } \\
\text { between SMEs and other businesses and } \\
\text { universities, various institutions of post-secondary } \\
\text { education, regional authorities, research centres } \\
\text { and scientific and technological poles (scientific } \\
\text { and technological parks, technopolises, etc.) }\end{array}$ & 21.24 & 87.15 & 410.32 & 0.00 & 0.00 & 644.62 \\
\hline 04 & $x_{4}$ & $\begin{array}{l}\text { Support for R \& TD, particularly in SMEs } \\
\text { (including access to services related to R \& TD } \\
\text { services in research centres) }\end{array}$ & 91.86 & 189.41 & 206.19 & 16.29 & 0.00 & $1,342.27$ \\
\hline 05 & $x_{5}$ & $\begin{array}{l}\text { Services in the field of advanced support for } \\
\text { companies and groups of companies }\end{array}$ & 144.68 & 149.08 & 103.04 & 112.24 & 0.23 & 870.62 \\
\hline 06 & $x_{6}$ & $\begin{array}{l}\text { Support for SMEs in the promotion of products and } \\
\text { environmentally friendly processes (introduction of } \\
\text { effective environmental management systems, } \\
\text { adoption and use of pollution prevention } \\
\text { technologies, integration of clean technologies into } \\
\text { company production) }\end{array}$ & 9.86 & 36.80 & 373.39 & 0.00 & 0.00 & 245.41 \\
\hline 07 & $x_{7}$ & $\begin{array}{l}\text { Investments in companies directly linked to } \\
\text { research and innovation (innovative technologies, } \\
\text { establishment of new enterprises by universities, } \\
\text { existing R \& TD centres and enterprises, etc.). }\end{array}$ & $1,265.45$ & $1,919.70$ & 151.70 & 654.71 & 0.00 & $13,508.25$ \\
\hline 08 & $x_{8}$ & Other investments in enterprises & 539.19 & 453.19 & 84.05 & 467.18 & 0.00 & $3,632.44$ \\
\hline 09 & $x_{9}$ & $\begin{array}{l}\text { Other measures to stimulate research and } \\
\text { innovation and entrepreneurship in SMEs }\end{array}$ & 33.60 & 96.43 & 286.95 & 0.64 & 0.00 & 757.79 \\
\hline
\end{tabular}


Cont. table 2 .

\begin{tabular}{|c|c|c|c|c|c|c|c|}
\hline$E a 2007 p c$ & The state of the economic aggregate in 2007 & 482.98 & 216.12 & 44.75 & 421.20 & 185.32 & $1,306.61$ \\
\hline Dependent variable & $E a 2013 p c$ & 669.35 & 296.19 & 44.25 & 580.39 & 296.55 & $1,857.60$ \\
\hline
\end{tabular}

Source: adapted from Commission Regulation (EC) No 1828/2006 of 8 December 2006, Annex II, pp. 31-34 and data available on the Portal of European Funds (PFE, 2014).

\section{Table 3.}

Key variable statistics representing independent variables in the counties $(N=111)$ for expenditure under the priority topic INFORMATION SOCIETY (variable InfrSI) 2007-2013

\begin{tabular}{|c|c|c|c|c|c|c|c|c|}
\hline $\begin{array}{l}\text { Intervention } \\
\text { code }\end{array}$ & Variable & Priority & $\begin{array}{l}\text { Mean } \\
\text { (PLN per } \\
\text { capita) }\end{array}$ & $\begin{array}{c}\text { Standard } \\
\text { deviation } \\
\text { (PLN per } \\
\text { capita) } \\
\end{array}$ & $\begin{array}{l}\text { Volatility } \\
\quad(\%)\end{array}$ & $\begin{array}{l}\text { Median } \\
\text { (PLN per } \\
\text { capita) }\end{array}$ & $\begin{array}{l}\text { Minimum } \\
\text { (PLN per } \\
\text { capita) }\end{array}$ & $\begin{array}{l}\text { Maximum } \\
\text { (PLN per } \\
\text { capita) }\end{array}$ \\
\hline 10 & $x_{10}$ & $\begin{array}{l}\text { Telecommunications infrastructure (including } \\
\text { broadband networks) }\end{array}$ & 147.68 & 156.65 & 106.08 & 92.47 & 0.00 & 628.94 \\
\hline 11 & $x_{11}$ & $\begin{array}{l}\text { Information and communication technologies (access, } \\
\text { security, interoperability, risk-prevention, research, } \\
\text { innovation, digital content, etc.). }\end{array}$ & 13.98 & 26.62 & 190.47 & 0.00 & 0.00 & 132.60 \\
\hline 13 & $x_{13}$ & $\begin{array}{l}\text { Services and applications for citizens (e-health, } \\
\text { e-government, e-education, e-inclusion, etc.). }\end{array}$ & 37.30 & 61.04 & 163.63 & 15.77 & 0.00 & 387.17 \\
\hline 14 & $x_{14}$ & $\begin{array}{l}\text { Services and applications for SMEs (e-commerce, } \\
\text { education and training, networking, etc.). }\end{array}$ & 27.34 & 51.08 & 186.83 & 12.15 & 0.00 & 387.02 \\
\hline 15 & $x_{15}$ & $\begin{array}{l}\text { Other measures to improve SMEs' access to ICT and } \\
\text { their efficient use }\end{array}$ & 100.04 & 80.59 & 80.57 & 78.97 & 0.00 & 431.74 \\
\hline
\end{tabular}

Source: adapted from Commission Regulation (EC) No 1828/2006 of 8 December 2006, Annex II, pp. 31-34 and data available on the Portal of European Funds (PFE, 2014). 
Table 4.

Key variable statistics representing independent variables in the counties $(N=111)$ for expenditure under the priority topic TRANSPORT (variable TR) 2007-2013

\begin{tabular}{|c|c|c|c|c|c|c|c|c|}
\hline $\begin{array}{l}\text { Intervention } \\
\text { code }\end{array}$ & Variable & Priority & $\begin{array}{c}\text { Mean } \\
\text { (PLN per } \\
\text { capita) }\end{array}$ & $\begin{array}{c}\text { Standard } \\
\text { deviation } \\
\text { (PLN per } \\
\text { capita) }\end{array}$ & $\begin{array}{c}\text { Volatility } \\
(\%)\end{array}$ & $\begin{array}{c}\text { Median } \\
\text { (PLN per } \\
\text { capita) }\end{array}$ & $\begin{array}{c}\text { Minimum } \\
\text { (PLN per } \\
\text { capita) }\end{array}$ & $\begin{array}{c}\text { Maximum } \\
\text { (PLN per } \\
\text { capita) }\end{array}$ \\
\hline 16 & $x_{16}$ & Railways & 183.07 & 517.07 & 282.44 & 7.81 & 0.00 & $3,532.08$ \\
\hline 17 & $x_{17}$ & Railways (TEN-T) & 217.38 & 887.22 & 408.14 & 24.50 & 0.00 & $8,152.49$ \\
\hline 18 & $x_{18}$ & Rolling stock & 114.87 & 315.70 & 274.83 & 30.13 & 0.00 & $2,478.29$ \\
\hline 19 & $x_{19}$ & Rolling stock (TEN-T) & 43.76 & 99.82 & 228.09 & 25.13 & 0.00 & 775.42 \\
\hline 20 & $x_{20}$ & Motorways & 353.27 & $1,473.53$ & 417.11 & 0.00 & 0.00 & $9,950.83$ \\
\hline 21 & $x_{21}$ & Motorways (TEN-T) & 975.96 & $2,847.79$ & 291.80 & 7.22 & 0.00 & $16,120.79$ \\
\hline 22 & $x_{22}$ & National roads & 38.74 & 158.72 & 409.65 & 2.85 & 0.39 & $1,186.48$ \\
\hline 23 & $x_{23}$ & Regional / local roads & 548.15 & 432.22 & 78.85 & 417.51 & 0.00 & $2,486.42$ \\
\hline 24 & $x_{24}$ & Cycle paths & 9.95 & 33.40 & 335.56 & 0.00 & 0.00 & 195.32 \\
\hline 25 & $x_{25}$ & City transport & 26.60 & 109.31 & 410.98 & 0.00 & 0.00 & 876.59 \\
\hline 26 & $\mathrm{X}_{26}$ & Multimodal transport & 10.07 & 63,38 & 629.62 & 0.00 & 0.00 & 533.44 \\
\hline 27 & $x_{27}$ & Multimodal transport (TEN-T) & 13.94 & 135,75 & 973.67 & 0.00 & 0.00 & $1,426.18$ \\
\hline 28 & $x_{28}$ & Intelligent transport systems & 11.75 & 50.73 & 431.67 & 0.00 & 0.00 & 385.05 \\
\hline 29 & $x_{29}$ & Airports & 28.78 & 192.10 & 667.57 & 0.00 & 0.00 & $1,808.16$ \\
\hline 30 & $x_{30}$ & Ports & 176.83 & $1,371.00$ & 775.33 & 0.00 & 0.00 & $14,333.79$ \\
\hline 31 & $x_{31}$ & Internal navigable waterways (regional and local) & 33.97 & 148.44 & 437.00 & 0.00 & 0.00 & 881.74 \\
\hline
\end{tabular}

Source: adapted from Commission Regulation (EC) No 1828/2006 of 8 December 2006, Annex II, pp. 31-34 and data available on the Portal of European Funds (PFE, 2014). 
Table 5.

Key variable statistics representing independent variables in the counties $(N=111)$ for expenditure under the priority topic ENERGY (variable NRG) 2007-2013

\begin{tabular}{|c|c|c|c|c|c|c|c|c|}
\hline $\begin{array}{l}\text { Intervention } \\
\text { code }\end{array}$ & Variable & Priority & $\begin{array}{c}\text { Mean } \\
\text { (PLN per } \\
\text { capita) }\end{array}$ & $\begin{array}{c}\text { Standard } \\
\text { deviation } \\
\text { (PLN per } \\
\text { capita) }\end{array}$ & $\begin{array}{c}\text { Volatility } \\
(\%)\end{array}$ & $\begin{array}{c}\text { Median } \\
\text { (PLN per } \\
\text { capita) }\end{array}$ & $\begin{array}{c}\text { Minimum } \\
\text { (PLN per } \\
\text { capita) }\end{array}$ & $\begin{array}{c}\text { Maximum } \\
\text { (PLN per } \\
\text { capita) }\end{array}$ \\
\hline 33 & $x_{33}$ & Electricity & 36.04 & 122.52 & 340.00 & 0.00 & 0.00 & 969.99 \\
\hline 35 & $x_{35}$ & Natural gas & 312.32 & 558.47 & 178.81 & 0.00 & 0.00 & $3,399.42$ \\
\hline 36 & $\mathrm{X}_{36}$ & Natural gas (TEN-T) & $1,230.59$ & $9,523.39$ & 773.89 & 0.00 & 0.00 & $88,488.69$ \\
\hline 39 & $x_{39}$ & Renewable energy: wind & 452.55 & $1,421.86$ & 314.19 & 0.00 & 0.00 & $8,866.45$ \\
\hline 40 & $x_{40}$ & Renewable energy: solar & 12.04 & 55.22 & 458.53 & 0.00 & 0.00 & 489.99 \\
\hline 41 & $x_{41}$ & Renewable energy: biomass & 19.85 & 75.81 & 381.83 & 0.00 & 0.00 & 435.68 \\
\hline 42 & $x_{42}$ & Renewable energy: hydroelectric, geothermal and other & 10.23 & 34.35 & 335.88 & 0.00 & 0.00 & 291.45 \\
\hline 43 & $x_{43}$ & Energy efficiency, co-generation (CHP), energy management & 169.14 & 194.74 & 115.13 & 93.02 & 3.89 & 935.61 \\
\hline
\end{tabular}

Source: adapted from Commission Regulation (EC) No 1828/2006 of 8 December 2006, Annex II, pp. 31-34 and data available on the Portal of European Funds (PFE, 2014).

\section{Table 6.}

Key variable statistics representing independent variables in the counties $(N=111)$ for expenditure under the priority topic INCREASING ADAPTABILITY OF WORKERS AND FIRMS, ENTERPRISES AND ENTREPRENEURS (variable RPAdapt) 2007-2013

\begin{tabular}{|c|c|c|c|c|c|c|c|c|}
\hline $\begin{array}{l}\text { Intervention } \\
\text { code }\end{array}$ & Variable & Priority & $\begin{array}{l}\text { Mean } \\
\text { (PLN per } \\
\text { capita) }\end{array}$ & $\begin{array}{l}\text { Standard } \\
\text { deviation } \\
\text { (PLN per } \\
\text { capita) }\end{array}$ & $\begin{array}{l}\text { Volatility } \\
\text { (\%) }\end{array}$ & $\begin{array}{l}\text { Median } \\
\text { (PLN per } \\
\text { capita) }\end{array}$ & $\begin{array}{l}\text { Minimum } \\
\text { (PLN per } \\
\text { capita) }\end{array}$ & $\begin{array}{l}\text { Maximum } \\
\text { (PLN per } \\
\text { capita) }\end{array}$ \\
\hline 62 & $x_{62}$ & $\begin{array}{l}\text { Development of learning systems and strategies for life in } \\
\text { enterprises; training and services to improve the adaptability } \\
\text { of workers to change; promoting entrepreneurship and } \\
\text { innovation }\end{array}$ & 184.23 & 111.62 & 60.59 & 146.62 & 27.35 & 538.14 \\
\hline 63 & $\mathrm{x}_{63}$ & $\begin{array}{l}\text { Development and dissemination of innovative and more } \\
\text { productive forms of work organization }\end{array}$ & 0.77 & 1.40 & 180.68 & 0.00 & 0.00 & 9.45 \\
\hline
\end{tabular}


Cont. table 6 .

\begin{tabular}{|c|c|l|c|c|c|c|c|c|}
\hline & $x_{64}$ & $\begin{array}{l}\text { Development of specific services for employment, training } \\
\text { and support in connection with restructuring of sectors and } \\
\text { businesses, development of systems for anticipating changes } \\
\text { in employment and skills needs and future requirements in } \\
\text { terms of employment and qualifications }\end{array}$ & 56.20 & 54.59 & 97.13 & 28.29 & 1.62 & 239.83 \\
\hline
\end{tabular}

Source: adapted from Commission Regulation (EC) No 1828/2006 of 8 December 2006, Annex II, pp. 31-34 and data available on the Portal of European Funds (PFE, 2014).

Table 7.

Key variable statistics representing independent variables in the counties $(N=111)$ for expenditure under the priority topic IMPROVING THE QUALITY OF HUMAN CAPITAL (variable RPKL) 2007-2013

\begin{tabular}{|c|c|c|c|c|c|c|c|c|}
\hline $\begin{array}{l}\text { Intervention } \\
\text { code }\end{array}$ & Variable & Priority & $\begin{array}{l}\text { Mean } \\
\text { (PLN per } \\
\text { capita) }\end{array}$ & $\begin{array}{l}\text { Standard } \\
\text { deviation } \\
\text { (PLN per } \\
\text { capita) } \\
\end{array}$ & $\begin{array}{c}\text { Volatility } \\
\text { (\%) }\end{array}$ & $\begin{array}{l}\text { Median } \\
\text { (PLN per } \\
\text { capita) }\end{array}$ & $\begin{array}{l}\text { Minimum } \\
\text { (PLN per } \\
\text { capita) }\end{array}$ & $\begin{array}{l}\text { Maximum } \\
\text { (PLN per } \\
\text { capita) }\end{array}$ \\
\hline 72 & $x_{72}$ & $\begin{array}{l}\text { Design, introduction and implementation of reforms in } \\
\text { education and training systems in order to improve } \\
\text { employability, increase the degree of adjustment of education } \\
\text { and initial training and vocational training to labour market } \\
\text { needs and updating skills of training personnel with a view } \\
\text { to an economy based on innovation and knowledge }\end{array}$ & 56.28 & 24.22 & 43.03 & 52.56 & 16.09 & 152.69 \\
\hline 73 & $x_{73}$ & $\begin{array}{l}\text { Measures to increase participation in education and training } \\
\text { for life, in particular by undertakings to reduce early school } \\
\text { leaving and to minimize discrimination based on gender and } \\
\text { by efforts to improve the quality and access to education and } \\
\text { training at the beginner, vocational and tertiary level }\end{array}$ & 236.46 & 92.23 & 39.00 & 214.28 & 53.77 & 627.63 \\
\hline 74 & $x_{74}$ & $\begin{array}{l}\text { Development of human potential in research and innovation, } \\
\text { in particular through post-graduate studies and training of } \\
\text { researchers, and networking activities between universities, } \\
\text { research centres and businesses }\end{array}$ & 39.18 & 19.01 & 48.50 & 35.19 & 5.08 & 114.26 \\
\hline
\end{tabular}

Source: adapted from Commission Regulation (EC) No 1828/2006 of 8 December 2006, Annex II, pp. 31-34 and data available on the Portal of European Funds (PFE, 2014). 


\section{Triple helix model in local innovation systems}

Local innovation system (LIS) can be defined as a collection of various private and public institutions and the relationships between them, working together for entrepreneurship, innovation and internationalization, leading to local development (see Fig. 1). In this definition three objectives have been highlighted, forming horizontal lines in a growing number of regional innovation strategies, tying up all the activities that can be undertaken within the RIS (RSMI, 2008, p. 67; UMWW, 2011, pp. 5-7). The presented sequence can be read in the following way: if the company is to apply for aid, it should be well managed (the level of entrepreneurship).

Principally, the relationships in the discussed triangle are not given in advance, are subject to dynamic change, and there is no analogy in this respect with the biological metaphor to which the concept refers. The most important features of the model include:

- the emergence of links between the three types of entities (science/business/ administration) responsible for the development of the knowledge-based economy and thus, for constantly increasing level of innovation in a given space, the most important player in this triad are enterprises, with science and administration take a supporting role to the innovation processes developed in enterprises;

- playing roles originally assigned to another type of entity, meaning that universities are beginning to be entrepreneurial, becoming a space for the creation of enterprises; moreover, they become key animators of the local community, often influencing the decisions of local and regional administration; meanwhile, the companies, sharing knowledge, training employees or participating in research projects, develop academic functions; authorities, acting according to principles of new public management, also become similar to companies, and in educating their employees, to universities,

- the formation of intermediate organizations located in the functional space between the types of entities; spin-offs, spin-outs, incubators and technology parks, research commercialization and patent rights protection offices, scientific networks, as well as local production agreements.

In the current discussion on THM from a regional and national approach, the result of the functioning of regional and national systems of innovation, reflecting the assumptions of the knowledge-based economy, was the number of patents implemented (Leydesdorff, 2012, p. 8, 9).

In this paper, the goal was to demonstrate the positive impact of public support on the relationships formed within the triple helix model for the local development of regions in Western Poland. The concept of the impact of public expenditure connected with the wider activities of innovation on local development, as proposed in the paper, was made more specific, formulating hypotheses based on the concept of creating relationships in the triple helix model (THM, Fig.1). 


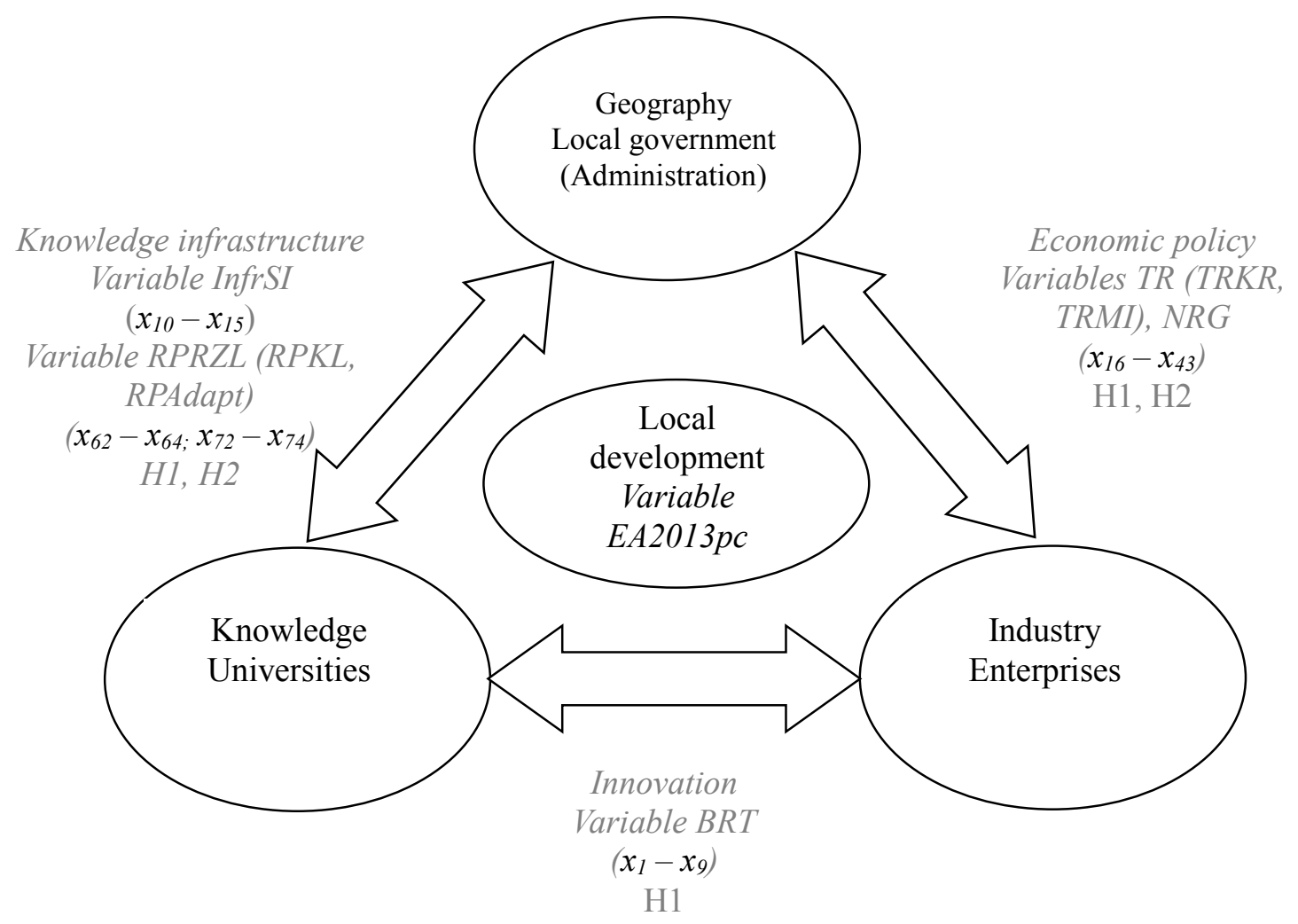

Figure 1. Verification diagram of hypotheses based on the assumptions of the triple helix model. Source: own elaboration.

The paper proposes two hypotheses, which express the following assumptions:

H1: a statistically significant impact on the local development of counties in Western Poland is due to public spending on innovation, technical infrastructure and knowledge infrastructure,

H2: expenditure on technical infrastructure has a greater impact on local development in counties in Western Poland than spending on knowledge infrastructure.

The first hypothesis is the result of observing the effect of THM on the development of countries and regions (Leydesdorff, 2012). There are two levels of impact on the development of the model. Researchers involved in THM assume that if there are synergy effects between the processes of cooperation between science, industry and administration (bi- and tri-lateral), the second-order interaction occurs in the knowledge economy (Leydesdorff, 2012, p. 9). The hypothesis $\mathrm{H} 1$ will be confirmed in the basic variant, if the regression parameter of at least one variable from the test set of 44 variables assigned to categories of intervention ${ }^{4}$ is statistically significant and greater than zero, which would indicate a positive impact on local development. Strong links for THM with local development will occur if at least one variable from each group of relationships; namely science-business (variables $x_{1}-x_{9}$ ), administrationscience (variables $x_{10-} x_{15}, \quad x_{62}-x_{64}$ and $\left.x_{72}-x_{74}\right)$, and administration-business $\left(x_{16}-x_{43}\right)$;

\footnotetext{
${ }^{4}$ The presented categories of intervention are in line with the nomenclature used in the cohesion policy of the European Union (Commission Regulation (EC) No 1828/2006 of 8 December 2006, Annex III, pp. 31-34), and data were collected on the basis of the statement of signed grant agreements executed on 30 September 2014 [PFE, 2014].
} 
is statistically significant and greater than zero. This will mean confirmation of the hypothesis $\mathrm{H} 1$ in the extended variant. In the case of at least one variable in the two groups of relationships, there will be a limited impact of THM on the local development in the extended variant.

The hypothesis $\mathrm{H} 2$ is linked to research on the impact of infrastructure on regional development (Gorzelak, 1997; 2009). Expenditure on technical infrastructure in this study is considered as a measure of the relationships created between administration and industry in the triple helix model. It should be noted, however, that infrastructure is a necessary, but not sufficient condition for the development of local innovation systems, and refers much more to stimulating entrepreneurship than stimulating innovation. Some very interesting findings for investment directions, depending on the level of development of an entity relate to research carried out in relation to the Central Appalachians from the 1960s. The construction of several thousand kilometres of two-lane highways caused an outflow of residents, mostly young, to the more developed regions (Gorzelak, 2009, p. 19-20). The scientists studying investments in technical infrastructure in Spanish regions (Pike, Rodrigues-Pose, and Tomaney, 2006) as well as German regions belonging to the former German Democratic Republic (Schaedklich, and Wagner, 2007, p. 15) reach similar conclusions. In the case of well-developed regions, which include Western Polish regions, the influence of technical infrastructure should be more favourable than in peripheral areas.

\section{Method of testing the impact of public support for the relationships formed within the triple helix model on the local development of the counties of Western Poland}

This paper assumes that a measure for the functioning of local innovation systems should be an economic aggregate (variable EA2013pc), which was established by multiplying the average salary in the district by the number of employees and dividing this by the number of inhabitants in the county. It assumes, moreover, that the county is a proper unit for the study of innovation at the local level, because municipalities are too small to stimulate innovation ${ }^{5}$, and the impact of regional authorities, which have competence to support entrepreneurship and innovation (Act on Regional Government of June 5, 1998, art. 11.1.3; art. 11.2.6), shows no signs of the proximity required in the development of local innovation systems (cf. Gaczek, 2009, p. 37-52). The units subjected to econometric study included all 111 counties grouped in the regions of Western Poland.

\footnotetext{
${ }^{5}$ As demonstrated by innovation research conducted in 2002-2006 in Greater Poland (Komorowski, Romanowski, and Gaczek, 2008, p. 58-60; Romanowski, 2005, p. 174-175).
} 
In research proceedings, based on econometric modelling, the relationships in the THM, concerning the links between science, industry and administration, have been treated as explanatory variables affecting the level of local development. The paper assumes that the measurement will include the relationships described by the cohesion policy expenditure for the different categories of intervention. Variable BRT, consisting of expenditure for the categories of intervention numbered 01-09, which are the basis of THM, was assigned to the mechanism of innovation to support the relationships between science and industry.

Variables TR and NGR, consisting of spending on categories of intervention numbered 16-31 (Transport) and 33-43 (Energy) were included among the measures falling within the competence of local governments which create a friendly climate for entrepreneurs in economic policy. A high level of technical infrastructure is treated as a basis for building a climate for entrepreneurship, although it should be remembered that the climate is a derivative of many other actions by the authorities. Infrastructure is treated as a necessary though insufficient condition for local innovation. The allocation of infrastructure spending to administrationindustry relations is a simplification, because such expenditure supports the functioning of the entire local community. In case of counties in Western Poland, no expenditure under intervention category 32 (Inland waterways (TEN-T)) and 34 (Electricity (TEN-T)) was recorded in 2007-2013.

The last set of expenses for activities in the development of knowledge infrastructure (variable InfrSI, consisting of spending on categories of intervention numbered 10-15), for human resources (HRD) directed to the labour market to working people (variable RPAdapt, composed of expenses on intervention categories numbered 62-64), and to support human capital, plus the education system including tertiary (variable RPKL, consisting of spending on categories of intervention numbered 72-74). These expenses represent the relationships between local government bodies and academic institutions in the triple helix model.

Thus selected, the set of 44 variables became the basis for verification of the hypotheses put forward in the paper. In addition, to improve the match of the theoretical model to the empirical data the set of explanatory variables included variable EA2007pc describing the level of economic aggregate in 2007. This variable is a measure of the state of socio-economic development in the first year of the cohesion policy from the 2007-2013 financial perspective, where public funds had not yet been disbursed. Variable EA2007pc represents a $45^{\text {th }}$ independent variable in the econometric model presented.

For the purposes of this study backward stepwise regression was employed, which enabled identification of only those variables, which, meeting the requirements of statistical significance, had the most influence on the dependent variable (EA2013pc). Elimination of variables was used a posteriori, whereby in the first step the regression model adopted all potential explanatory variables, and then it excluded those which did not meet the statistical significance criteria (Nowosielska, 1977). Due to the complexity of the calculations for stepwise regression, modelling was performed using STATISTICA, a universal system used for statistical data analysis. 
To prove the hypotheses, a set of 45 independent variables was used (variables $x_{1}-x_{43}, x_{62}-$ $x_{64}, x_{72}-x_{74}$ and $E A 2007 p c^{6}$ ), of which, in the successive steps of backward elimination, four remained in the final version of the model $\left(x_{7}, x_{14}, x_{35}\right.$ and EA2007pc), and the requested relationship equation between variables took the following form:

\section{EA2013pc'PolZach ${ }_{45}=72.78+0.016 x_{7}+0.65 x_{14}-0.04 x_{35}+1.18 E A 2007 p c$}

The parameters of the regression function showed statistical significance $(p<0.05)$, and the coefficient of R2 determination was 0.948 . This means that the constructed model explained nearly $95 \%$ of dependent variable changes. The value of adjusted R2 (taking into account the number of independent variables in the model), amounting to 0.946 , did not differ significantly from the general factor (Table 8).

\section{Table 8.}

Key statistics for backward stepwise multiple regression model for the 45 LIS variablesEA2013pc'PolZach 45 in all the counties of Western Poland $(N=111)$

\begin{tabular}{|c|c|c|c|c|}
\hline \multirow[t]{2}{*}{$N=111$} & \multicolumn{4}{|c|}{$\begin{array}{l}R^{2}=0.94804136 ; \text { Adjusted } R^{2}=094,608,065 \\
\text { Degrees of freedom: } 106 \\
F(4.106)=483.52, p<0.0000 \\
\text { Standard error of estimation: } 68.778\end{array}$} \\
\hline & Coefficient & Standard error & t-Statistics & Probability \\
\hline Intercept & 72.77935 & 17.81168 & 4.08605 & 0.000086 \\
\hline$x_{7}$ & 0.01627 & 0.00357 & 4.55853 & 0.000014 \\
\hline$x_{14}$ & 0.65006 & 0.16145 & 4.02643 & 0.000107 \\
\hline$x_{35}$ & -0.04044 & 0.01185 & -3.41369 & 0.000909 \\
\hline$E A 2007 p c$ & 1.18191 & 0.03930 & 30.07744 & 0.000000 \\
\hline
\end{tabular}

Source: own calculations.

The model demonstrates that the part of the volatility of the economic aggregate at the local level for the 111 counties of Western Poland being described (EA2013pc'PolZach ${ }_{45}$ ) was mostly affected, in addition to the state of development in 2007 (EA2007pc), by expenditure on investment in enterprises directly linked to research and innovation (innovative technologies, establishment of new firms by universities, existing R\&D centres and enterprises, etc.; variable $x_{7}$ ). This variable was included in the most important relationships in the triple helix model, i.e. the science-business relationship.

The second variable positively affecting the level of local development, as measured by variable EA2013pc, was variable $\mathrm{x}_{14}$, responsible for public expenditure on services and applications for SMEs (e-commerce, education and training, networking, etc.). Due to the advantages of training and recognition of education within the category of intervention number 14, variable $x_{14}$ was included in the administration-science relationship in the triple helix model. However, it is worth noting that applications for small and medium-sized enterprises, created with public money, intended for training programmes and raising the level of knowledge, bear the hallmarks of tri-lateral relationships, so highly recommended in the triple helix model.

\footnotetext{
${ }^{6}$ Due to the mentioned lack of spending in the categories of intervention 32 and 34 in the counties of Western Poland in 2007-2013 variables $x_{32}$ and $x_{34}$ were removed from the established set.
} 
These variables, being statistically significant, are stimulants. Every zloty spent on investments in companies linked to research and innovation in 2007-2013 increased the value of the economic aggregate by more than 1.5 grosz, and spending on services and applications for SMEs - by more than 65 grosz.

Meanwhile, a statistically significant destimulant in the presented model is expenditure on natural gas (variable $x_{35}$ ), because the regression parameter of this variable is less than zero, which may result from investments in gas infrastructure in the counties lagging behind, not growing particularly rapidly.

Analysis of the model described using the presented equation confirms hypothesis H1 in the basic variant, because local development was positively affected by spending on innovation carried out in companies at the junction of the science-business relationship (variable $x_{7}$ ) and at the administration-science junction (variable $x_{14}$ ). Thus, there was a bi-lateral relationship involving the interdependence of expenditure for pro-innovative investment in enterprises and the creation of programmes to raise the level of knowledge with the level of local development, which means adopting hypothesis $\mathrm{H1}$ in the extended variant.

On the other hand, hypothesis $\mathrm{H} 2$, according to the above observation, must be rejected, since the only variable responsible for technical infrastructure being statistically significant (variable $x_{35}$ ) was the destimulant of local development assuming the invariance of other variables.

\section{Summary}

The purpose of this paper was to demonstrate the positive impact of public support for the relationships formed within the triple helix model on the local development of the regions of Western Poland. The commonly repeated opinions on the necessity of expenditure on these objectives have been subjected to econometric measurement. The results of the regression model applied confirm the positive impact of expenses related to the broadly understood innovation activities on local development, particularly in relation to investments in companies related to innovation activities and expenditure on knowledge infrastructure, especially services and applications for SMEs. These expenses represent the science-business and administrationscience relationships in the triple helix model. Therefore, one can draw a conclusion about the positive effects of allocating limited funds, both public and private, in this type of activity in the years 2015-2020 in the regions of Western Poland at the local level.

In contrast, expenditure on technical infrastructure, representing the administrationbusiness relationship in the triple helix model, demonstrates a negative impact on the adopted local development measures. Typically, investments in technical infrastructure are recommended in more developed regions. However, the only statistically significant variable describing expenses for this purpose in the study was the destimulant of local development. 
The triple helix model is a reflection of the relationships that should exist in local innovation systems regardless of the region and the level of socio-economic potential. However, in line with the new institutional economics, each community should create and develop relationships in accordance with local conditions, organizational culture and the values important for the community. Regardless of the institutions present in the community, the best results are obtained with trilateral relationships occurring at the interface of science-businessadministration. Such relations, in bilateral terms, have been diagnosed at the interface of science-business and administration-science, although tri-lateral relationships can also be traced, as variable $x_{14}$ is responsible for raising the level of knowledge in the sector of small and medium-sized enterprises. It can therefore be concluded that spending on relationships created in the triple helix model, implemented under the Cohesion Policy in 2007-2013 in the counties of Western Polish regions had positive impact on local development. Importantly, in the surveyed counties, the noticeable bi-lateral synergistic effects are better than for the less developed border counties of Eastern Poland (Romanowski, 2016).

\section{Refernces}

1. Act of 5 June 1998 on local governments, consolidated text, Journal of Laws 2013, Item 76.

2. CEC (2005). Community Lisbon programme. Common efforts for growth and employment. Brussels: Commission of the European Communities, http://www.europarl.europa.eu/ meetdocs/2004_2009/documents/com/com_com(2005)0330_/com_com(2005)0330_pl.pdf, 19.01.2015.

3. Commission Regulation (EC) No. 1828/2006 of 8 December 2006 laying down detailed rules for the implementation of Council Regulation (EC) No. 1083/2006 laying down general provisions on the European Regional Development Fund, the European Social Fund and the Cohesion Fund and of Regulation (EC) No. 1080/2006 of the European Parliament and the Council on the European Regional Development Fund; Annex III: List of data on operations to be communicated on request of the Commission for the purpose of documentary and on-site audit under Article 14, Official Journal of the EU L 45/3, http://www.ncbir.pl/gfx/ncbir/userfiles/_public/pl_1828_wykonawcze_corr_2_02_2007. pdf, 11.11.2015.

4. EC (2010). Europa 2020. Strategy for smart, sustainable and inclusive growth. Brussels: European Commission, http://ec.europa.eu/eu2020/pdf/1_PL_ACT_part1_v1.pdf.

5. Etzkowitz, H., Leydesdorff, L. (1995). The Triple Helix - University - Industry Government Relations: A Laboratory for Knowledge Based Economic Development. EASST Review, 14. 
6. Gaczek, W.M. (ed.) (2005). Innowacje w rozwoju regionu. Wydawnictwo Akademii Ekonomicznej w Poznaniu.

7. Gaczek, W.M., Stryjakiewicz, T. (ed.) (2008). Ocena realizacji celów Regionalnej Strategii Innowacji oraz stanu systemu innowacji w Wielkopolsce: wyniki badań monitorujacych. Poznań: Fundacja UAM - Poznański Park Naukowo-Technologiczny.

8. Gorzelak, G. (1997). Polityka pomocy regionalnej w liberalnej gospodarce - Appalachy. In: A. Dobroczyńska (ed.), Jednolitość i różnorodność w polityce rozwoju. Wydział Nauk Ekonomicznych Uniwersytetu Warszawskiego.

9. Gorzelak, G. (2009). Fakty i mity rozwoju regionalnego. Studia Regionalne i Lokalne, 2(36).

10. GUS (2016). Historia nomenklatury NTS. Warsaw: Central Statistical Office, http://stat.gov.pl/statystyka-regionalna/jednostki-terytorialne/nomenklatura-nts/historianomenklatury-nts/, 31.03.2016.

11. Komorowski, J., Romanowski, R., Gaczek, W.M. (2008). Integracja środowisk społecznogospodarczych na rzecz innowacji - ocena realizacji 1. Celu strategicznego Regionalnej Strategii Innowacji dla Wielkopolski. In: W.M. Gaczek, T. Stryjakiewicz, (eds.), Ocena realizacji celów Regionalnej Strategii Innowacji oraz stanu systemu innowacji w Wielkopolsce: wyniki badań monitorujacych. Poznań: Fundacja UAM - Poznański Park Naukowo-Technologiczny.

12. Leydesdorff, L. (2012). The Triple Helix of University-Industry-Government Relations, http://www.leydesdorff.net/th12/th12.pdf, 3.05.2015.

13. Nowosielska, E. (1977). Analiza regresji w badaniach geograficznych. In: Z. Chojnicki (ed.), Metody ilościowe i modele w geografii. Warsaw: PWN.

14. NSRF (2007). National Strategic Reference Framework 2007-2013 supporting economic growth and employment. National Cohesion Strategy. Warsaw: Ministry of Regional Development, http://www.mos.gov.pl/g2/big/2009_06/2c314c2465263751e64b99ef97ad 656e.pdf, 11.11.2015.

15. Parysek, J.J., Wojtasiewicz, L. (1979). Metody analizy regionalnej i metody planowania regionalnego. Studia KPZK PAN, 69, Warsaw.

16. PFE (2014). Umowy o dofinansowanie wg projektów, programów, poziomów wdrażania, województw, powiatów, gmin, danych dotyczacych beneficjentów, tematu priorytetu i formy prawnej. Warsaw: Portal Funduszy Europejskich, http://www.funduszeeuropejskie.gov.pl/ AnalizyRaportyPodsumowania/Strony/KSI_raporty.aspx, 10.10.2015.

17. Pike, A., Rodrigues-Pose, A., Tomaney, J. (2006). Local and Regional Development. London-New York: Routledge.

18. Romanowski, R. (2005). Możliwości rozwoju terytorialnych systemów produkcyjnych w Wielkopolsce. In: W.M. Gaczek (ed.), Innowacje w rozwoju regionu. Wydawnictwo Akademii Ekonomicznej w Poznaniu. 
19. Romanowski, R. (2015). Wplyw wsparcia systemów innowacji na rozwój lokalny. Wydawnictwo Uniwersytetu Ekonomicznego w Poznaniu.

20. Romanowski, R. (2016). The impact of local innovation systems support on local development for cross-border regions of the Eastern Poland. Krakow: Centre for Strategic and International Entrepreneurship.

21. RSIM (2008). Regionalna Strategia Innowacji dla Mazowsza 2007-2015, Załącznik do Uchwały Nr 72/08 Sejmiku Województwa Mazowieckiego z dnia 21 kwietnia 2008 roku, Warsaw, http://staze.teklaplus.pl/wp-content/themes/tekla/Mazowieckie_RSI.PDF, 12.01.2014.

22. Schaedklich, M., Wagner, G. (2007). Perspectives and Opinions for Economic Policy in Eastern Germany - with Special Reference to Aspects from Spatial Sciences. In: S. Lenz (ed.), Restructuring Eastern Germany (German Annual of Spatial Research and Policy). Berlin-Heidelberg-New York: Springer.

23. SL (2000). Strategia Lizbońska - droga do sukcesu zjednoczonej Europy. Urząd Komitetu Integracji Europejskiej, www.ukie.gov.pl. 1.04.2012.

24. UKIE (2002). Strategia lizbońska. Droga do sukcesu zjednoczonej Europy. Departament Analiz Ekonomicznych i Społecznych Urzędu Komitetu Integracji Europejskiej, https://www.slaskie.pl/STRATEGIA/strat_L.pdf.

25. UMWW (2011). Model rozwoju Wielkopolski w oparciu o innowacje. Urząd Marszałkowski Województwa Wielkopolskiego, Poznań, https://wrot.umww.pl/wrot-test/wp-content/ uploads/2014/07/RSI_Model.pdf, 12.01.2014.

26. Watson, J., Crick, F. (1953). A Structure for Deoxyribose Nucleic Acid. Nature, 171, 4356, 737-738. 